Technical Note

\title{
Technical Note: Effects of Makeshift Storage in Different Liquors on Larvae of the Blowflies Calliphora vicina and Lucilia sericata (Diptera: Calliphoridae)
}

\author{
Senta Niederegger (D)
}

check for

updates

Citation: Niederegger, S. Technical Note: Effects of Makeshift Storage in Different Liquors on Larvae of the Blowflies Calliphora vicina and Lucilia sericata (Diptera: Calliphoridae). Insects 2021, 12, 312. https://doi.org/10.3390/insects12040312

Academic Editors:

Damien Charabidze and

Daniel Martín-Vega

Received: 26 February 2021

Accepted: 29 March 2021

Published: 1 April 2021

Publisher's Note: MDPI stays neutral with regard to jurisdictional claims in published maps and institutional affiliations.

Copyright: (C) 2021 by the author. Licensee MDPI, Basel, Switzerland. This article is an open access article distributed under the terms and conditions of the Creative Commons Attribution (CC BY) license (https:// creativecommons.org/licenses/by/ $4.0 /)$.
Department of Forensic Entomology, Institute of Legal Medicine at the University Hospital Jena, 07740 Jena, Germany; senta.niederegger@med.uni-jena.de

Simple Summary: Sometimes, police need to collect fly maggots as evidence. If the proper equipment is not at hand, alternatives might need to be found. This evidence can later be given to a forensic entomologist for further examination. The alternative methods, however, can have unknown effects on the samples. We placed maggots in different alcoholic beverages and measured size changes happening over time to provide experts with such information. Our results show that low alcohol beverages can cause samples to shrink. With knowledge about these specific effects, the samples can still be used for casework in forensic entomology.

Abstract: Unexpected findings of forensically important insects might prompt makeshift storage in alternative liquids if the proper equipment is lacking. The assessment of whether such evidence can still be used and correctly interpreted can be difficult. In this study, the effects of using alcoholic beverages as storing agents for post-feeding larvae of Calliphora vicina and Lucilia sericata were analyzed. Larvae were killed with boiling water (HWK) or placed alive into four alcoholic liquids: two spirits, vodka and brandy, and two liquors, Jägermeister and peppermint schnapps. Storage effects were documented after one day, nine days, and one month and compared to larvae treated according to guidelines for forensic entomology. Results show that the method of killing larvae is more important than the storing medium. Storage of HWK larvae in high-alcohol/low-sugar spirits had almost negligible effects on both species, while all fresh larvae shrank significantly. High sugar contents of the beverages might additionally lead to shrinkage of larvae.

Keywords: forensic entomology; biological variation; death time estimation; alternative storage; casework

\section{Introduction}

Forensically relevant flies deposit their eggs on cadavers and carrion where their offspring hatch, feed, and develop [1,2]. This process was described and even denominated as a "biological clock" for the estimation of the minimal postmortem interval (mPMI) [3,4].

Oftentimes, human bodies colonized by fly larvae are discovered within a domestic setting. In many instances, investigators might presume natural death. Police personnel, as a precaution, might still want to collect and preserve a number of larvae. Circumstances indicating a crime might become known only after the body was cremated and the apartment cleaned. It can take an unpredictable amount of time for a previously unsuspicious death to change into the result of a crime.

The guidelines of forensic entomology [5], which recommend using boiling water for killing and fixation and ethanol for storage of fly larvae, should always be followed when collecting and storing insect evidence. The best medium for storage in forensic entomology casework is 70-80\% ethanol [6], while some even suggest 70-95\% ethanol [7]. The effect of numerous other media of known fly larvae killing and preservation methods have been investigated, from formaldehyde [6,8] to Kahle's solution [8] and San Veino [9]. Investigators, however, might not always be able to provide ethanol, other chemicals, 
or hot water when larvae are unexpectedly found at a scene. In such cases, imaginative caseworkers might turn to materials at hand for emergency storage of larvae. Oftentimes, a range of alcoholic spirits or liquors are present right at the scene or a liquor store is nearby.

The aim of this study was to evaluate whether such evidence can still be interpreted and the results presented in court. To achieve this, post-feeding larvae of two species were treated as recommended in the guidelines, but stored in easily achievable alcoholic liquids, as well as $70 \%$ ethanol. Furthermore, living larvae were killed by transferring them directly into the tested liquors. Effects of storage up to one month were investigated.

\section{Materials and Methods}

Larvae of two forensically important fly species were used in this study: Calliphora vicina Robineau-Desvoidy, 1830 and Lucilia sericata (Meigen, 1826) from laboratory colonies kept in a climatic chamber at $21{ }^{\circ} \mathrm{C}$ with $60 \%$ humidity. Larval age was synchronized by $24 \mathrm{~h}$ periods, during which flies were offered minced meat for oviposition. Emerging larvae were left undisturbed in a rearing container for six days until most had reached peak length and started migration.

The larvae were extracted from the rearing container and randomly assigned to two treatments and five storing liquids. Fresh larvae were transferred directly into their assigned liquids. HWK (hot-water-killed) larvae were killed by placing not more than 20 individuals at a time in a tea strainer and doused with boiling water for at least $20 \mathrm{~s}$; after dabbing with a paper towel, they were transferred to their assigned liquids. The abbreviation HWK (hot-water-killed) was established for this method of killing before [6] and maintained even though boiling and not just hot water was used.

To investigate the effect of alcoholic beverages as storage agents, popular spirits like vodka (Kaliskaya, 37.5\% vol.) and brandy (Chantré, 36\% vol.), as well as liquor specialties like Jägermeister (35\% vol.), a well-known brand of herbal liquor as representative for locally diverse brands, and peppermint schnapps (18\% vol.) due to its low alcohol content, were used. Fresh larvae were also stored in $70 \%$ ethanol. A second trial was performed five days later, for a total of 350 larvae (Table 1).

Table 1. Average sizes $\left( \pm \mathrm{SD}^{1}\right)$ and size ranges of larvae in first measurement (1 day) in mm, controls are HWK larvae stored in $70 \%$ ethanol for 1 day.

\begin{tabular}{ccccccc}
\hline \multirow{2}{*}{ Sizes } & \multicolumn{3}{c}{ Calliphora vicina } & \multicolumn{3}{c}{ Lucilia sericata } \\
\cline { 2 - 7 } & Fresh & HWK $^{2}$ & Control & Fresh & HWK $^{2}$ & Control \\
& $\boldsymbol{n = 1 0 0}$ & $\boldsymbol{n = 8 0}$ & $\boldsymbol{n = 2 0}$ & $\boldsymbol{n = 7 5}$ & $\boldsymbol{n = 6 0}$ & $\boldsymbol{n = 1 5}$ \\
\hline average & $14.7( \pm 1.2)$ & $15.9( \pm 1.2)$ & $16.1( \pm 0.9)$ & $12.7( \pm 0.9)$ & $14.0( \pm 1.5)$ & $15.2( \pm 0.7)$ \\
range & $12.0-17.01$ & $13.3-18.4$ & $14.5-17.9$ & $10.3-15.1$ & $10.8-16.3$ & $13.6-16.3$ \\
\hline
\end{tabular}

${ }^{1} \mathrm{SD}=$ standard deviation, ${ }^{2} \mathrm{HWK}=$ hot-water-killed.

HWK post-feeding larvae of C. vicina and L. sericata stored in $70 \%$ ethanol were used as control and their lengths at the respective time served as reference points for both HWK and fresh larvae.

For each measurement, larvae were extracted from their vials, placed into a petri dish, photographed with a camera and a Zeiss Stereomicroscope Stemi 2000, and put back into their original vials without changing the storing medium. Length of the larvae was measured using Zeiss software in the images yielded from the microscope and documented.

In the first trial, maggots were measured after $2 \mathrm{~h}$, but because at least $25 \%$ of the fresh larvae were still alive after this time, the data were disregarded and the measurement was not repeated. Subsequent length measurements were performed after 1 day, 9 days, and 1 month. These periods were deemed reasonable for domestic deaths to potentially change from unsuspicious to ominous.

A nonparametric Mann-Whitney $U$ test was performed to compare samples of different sample sizes to their control group. Statistical analyses were conducted using IBM SPSS Statistics 26. 
Storage temperature was not altered from laboratory average temperature of $20^{\circ} \mathrm{C}$, as a study of Richards et al. [10] showed no statistically significant effect of storage temperature between $-25^{\circ} \mathrm{C}$ and $+24{ }^{\circ} \mathrm{C}$ in larval length and weight.

\section{Results}

When living fly larvae were placed directly into their respective storage liquids, all animals squirmed and contracted (Figure 1a). Larvae were still alive for up to three hours in their respective media. Killing with boiling water, on the other hand led to death and instant straightening of the whole body (Figure 1b). The first length measurements were performed after one day (Table 1).

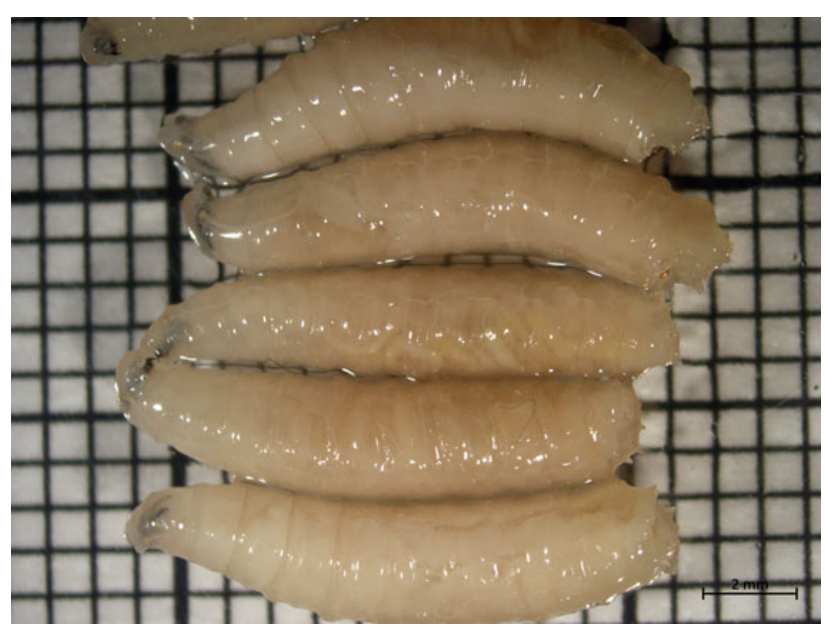

(a)

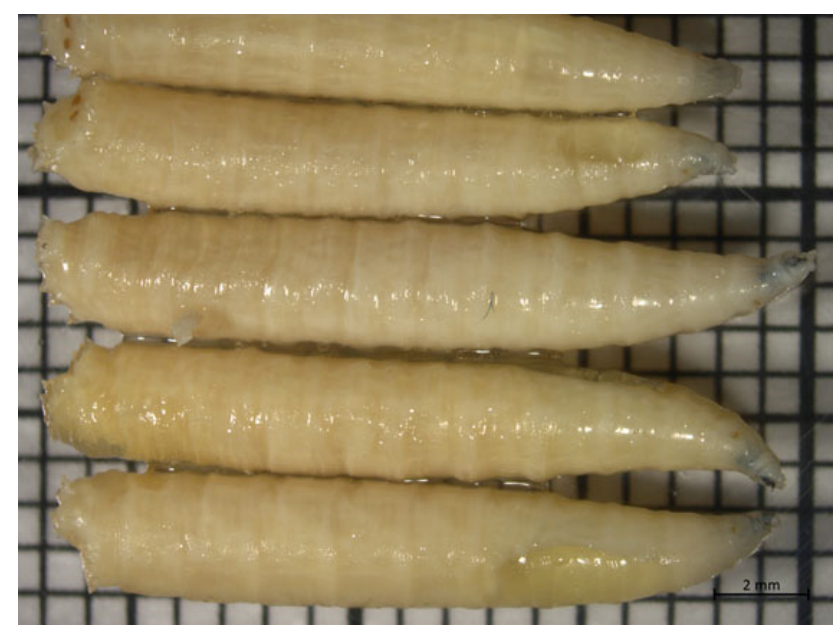

(b)

Figure 1. Larvae of Calliphora vicina after one day in 70\% ethanol, (a) fresh: larvae placed into liquid while alive, (b) HWK: larvae hot-water-killed before placement in liquid.

The first experiment compared lengths of HWK larvae of both species stored in alternative alcoholic liquids to their counterparts treated according to the guidelines for forensic entomology [5] in 70\% ethanol (Figure 2 and Table 2).

After one day, sizes of all C. vicina larvae in all spirits and liquors were within two percent points compared to controls, and thus not significantly different. Larvae in peppermint schnapps over time remained shorter than the control, but in a statistically nonrelevant range. Samples in Jägermeister shrank most and resulted in significantly shorter larvae than the controls. Lengths of larvae in the two spirits, vodka and brandy, in contrast, slightly increased to more than $100 \%$ of the size of control larvae over time, but differences were not statistically significant (Table 2).

Larvae of $L$. sericata in alternative liquids were $6-18 \%$ smaller than their controls on day one, and thus significantly different. Over time, larvae stored in brandy expanded the most and their lengths reached $99 \%$ of the size of controls. Larvae in vodka reached $97 \%$ of the size of controls by the end of the storage time of one month. These differences were no longer statistically significant (Table 2). Sizes of larvae in Jägermeister and peppermint schnapps differed more from controls over time. Lengths of larvae in Jägermeister shrank from $91 \%$ on day 1 to $83 \%$ of the size of controls after one month. Larvae in peppermint schnapps shrank from $82 \%$ to $79 \%$ on day nine, but reversed to $81 \%$ by one month storage time (Figure 2). 


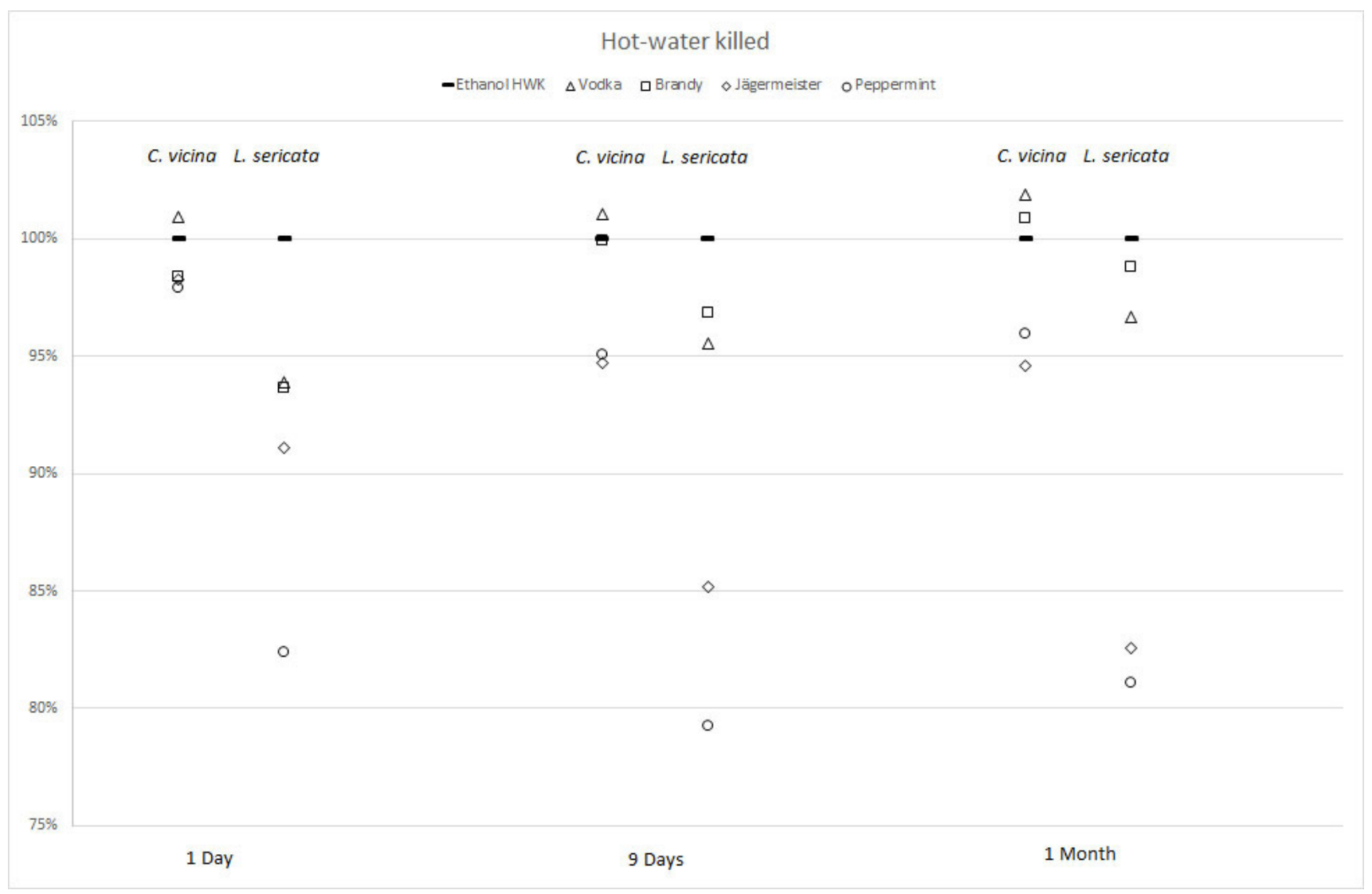

Figure 2. Percentage changes in lengths for Calliphora vicina (left column) and Lucilia sericata (right column) post-feeding larvae after hot-water-killing (HWK) and storage in four alcoholic liquids for 1 day, 9 days, and 1 month compared to HWK larvae in $70 \%$ ethanol $(=100 \%)$.

Table 2. Average sizes of Calliphora vicina and Lucilia sericata larvae in $\mathrm{mm}$, standard deviations ( \pm SD), and number of larvae $(\mathrm{n})$ measured after 1 day $(1 \mathrm{~d})$ and after 1 month $(1 \mathrm{~m})$ in alcoholic liquids, alcoholic content given in \% vol., grey fields indicate controls.

\begin{tabular}{|c|c|c|c|c|c|c|c|c|}
\hline \multirow{3}{*}{$\begin{array}{l}\text { Alcoholic } \\
\text { Liquid }\end{array}$} & \multicolumn{4}{|c|}{ Calliphora vicina } & \multicolumn{4}{|c|}{ Lucilia sericata } \\
\hline & \multicolumn{2}{|c|}{ Fresh } & \multicolumn{2}{|c|}{ HWK $^{1}$} & \multicolumn{2}{|c|}{ Fresh } & \multicolumn{2}{|c|}{ HWK $^{1}$} \\
\hline & $1 \mathrm{~d}$ & $1 \mathrm{~m}$ & $1 \mathrm{~d}$ & $1 \mathrm{~m}$ & $1 \mathrm{~d}$ & $1 \mathrm{~m}$ & $1 \mathrm{~d}$ & $1 \mathrm{~m}$ \\
\hline Ethanol 70\% & $\begin{array}{c}12.8^{*} \\
( \pm 1.2) n=20\end{array}$ & $\begin{array}{l}13.8^{*} \\
( \pm 1.2)\end{array}$ & $\begin{array}{c}16.3 \\
( \pm 0.9) n=20\end{array}$ & $16.1( \pm 0.9)$ & $\begin{array}{c}12.2 * \\
( \pm 0.9) n=15\end{array}$ & $\begin{array}{l}12.8^{*} \\
( \pm 0.8)\end{array}$ & $\begin{array}{c}15.5 \\
( \pm 0.6) n=15\end{array}$ & $\begin{array}{r}15.2 \\
( \pm 0.7)\end{array}$ \\
\hline Vodka $37.5 \%$ & $\begin{array}{c}13.1 * \\
( \pm 1.0) n=20\end{array}$ & $\begin{array}{l}15.2 * \\
( \pm 0.8)\end{array}$ & $\begin{array}{c}16.5 \\
( \pm 1.2) n=20\end{array}$ & $\begin{array}{c}16.4 \\
( \pm 1.1)\end{array}$ & $\begin{array}{c}11.5 * \\
( \pm 0.6) n=15\end{array}$ & $\begin{array}{l}12.8^{*} \\
( \pm 0.9)\end{array}$ & $\begin{array}{c}14.6^{*} \\
( \pm 0.7) n=15\end{array}$ & $\begin{array}{r}14.7 \\
( \pm 0.7)\end{array}$ \\
\hline Brandy $36 \%$ & $\begin{array}{c}14.2 * \\
( \pm 1.8) n=20\end{array}$ & $\begin{array}{l}15.3^{*} \\
( \pm 1.0)\end{array}$ & $\begin{array}{c}16.0 \\
( \pm 1.2) n=20\end{array}$ & $\begin{array}{c}16.3 \\
( \pm 1.2)\end{array}$ & $\begin{array}{c}12.1 \text { * } \\
( \pm 0.8) n=15\end{array}$ & $\begin{array}{l}13.2^{*} \\
( \pm 1.0)\end{array}$ & $\begin{array}{c}14.5^{*} \\
( \pm 0.8) n=15\end{array}$ & $\begin{array}{r}15.1 \\
( \pm 1.0)\end{array}$ \\
\hline Jägermeister $35 \%$ & $\begin{array}{c}13.7 * \\
( \pm 1.7) n=20\end{array}$ & $\begin{array}{l}14.6^{*} \\
( \pm 1.1)\end{array}$ & $\begin{array}{c}16.0 \\
( \pm 1.1) n=20\end{array}$ & $\begin{array}{l}15.2 * \\
( \pm 1.1)\end{array}$ & $\begin{array}{c}11.7 * \\
( \pm 1.0) n=15\end{array}$ & $\begin{array}{l}12.3^{*} \\
( \pm 0.6)\end{array}$ & $\begin{array}{c}14.1 * \\
( \pm 0.7) n=15\end{array}$ & $\begin{array}{l}12.6^{*} \\
( \pm 1.1)\end{array}$ \\
\hline Peppermint $18 \%$ & $\begin{array}{c}13.9^{*} \\
( \pm 1.8) n=20\end{array}$ & $\begin{array}{l}14.6 \text { * } \\
( \pm 1.3)\end{array}$ & $\begin{array}{c}16.0 \\
( \pm 1.3) n=20\end{array}$ & $\begin{array}{c}15.5 \\
( \pm 1.3)\end{array}$ & $\begin{array}{c}12.1 \text { * } \\
( \pm 1.0) n=15\end{array}$ & $\begin{array}{l}12.3^{*} \\
( \pm 0.9)\end{array}$ & $\begin{array}{c}12.8 * \\
( \pm 1.0) n=15\end{array}$ & $\begin{array}{l}12.4^{*} \\
( \pm 0.9)\end{array}$ \\
\hline
\end{tabular}

${ }^{1} \mathrm{HWK}=$ hot-water-killed, ${ }^{*}$ statistically significant differences compared to controls (Mann-Whitney U test).

The second experiment compared fresh larvae stored in 70\% ethanol and alternative liquids without previous hot-water-killing to the same control group of HWK larvae in $70 \%$ ethanol (Figure 3). 


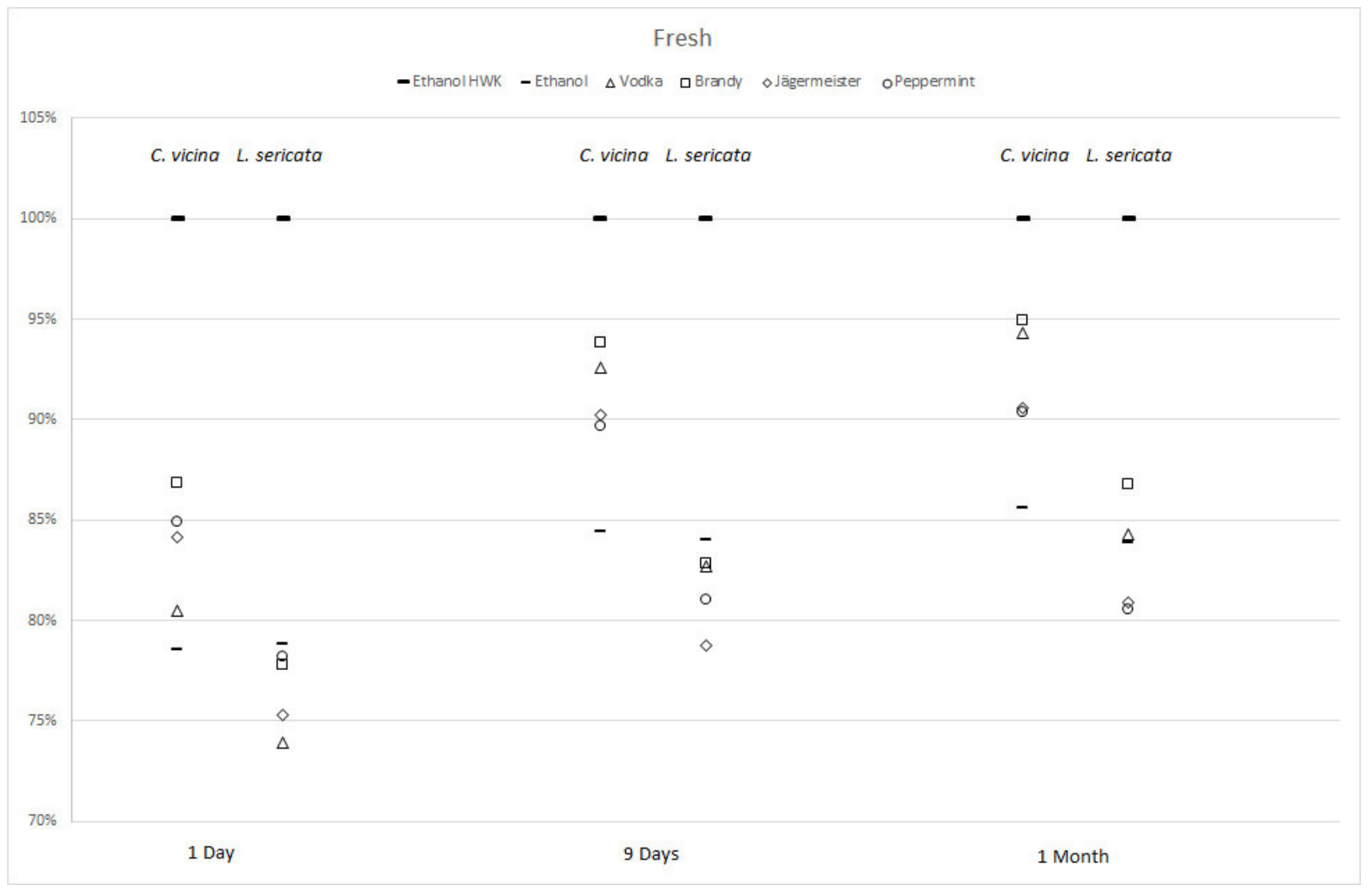

Figure 3. Percentage changes in lengths for Calliphora vicina (left columns) and Lucilia sericata (right columns) post-feeding larvae stored alive in five alcoholic liquids for 1 day, 9 days, and 1 month compared to hot-water-killed (HWK) larvae in $70 \%$ ethanol.

All freshly stored larvae were smaller than their HWK controls and all differences were statistically significant (Table 2). On day one, $C$. vicina larvae freshly stored in ethanol were $22 \%$ smaller, and fresh L. sericata larvae in ethanol were $21 \%$ smaller than their controls. These values represented the lowest discrepancy for L. sericata, while it was the highest recorded for C. vicina.

While the differences in sizes between fresh larvae of $L$. sericata and their control group were larger than in C. vicina, the range of variation between liquids tested was larger in C. vicina. Sizes of fresh larvae in all liquids over time approximated the sizes of control larvae for both species, but differences remained significantly different (Table 2).

\section{Discussion}

The effect of numerous methods of scientific killing and preservation for fly larvae have been investigated [1,6-10] to date. No investigations, however, have been conducted on the effects of improvised methods, such as the use of alcoholic beverages for storage of fly larvae, which might become necessary due to a lack of equipment.

For this study, post-feeding C. vicina and L. sericata aged six days were used. Numerous aspects concerning the larvae of these two forensically important species are well investigated [11-44]. At constant temperatures of about $20^{\circ} \mathrm{C}$, they develop at very similar rates. Days to maximum length, and thus the beginning of the nonfeeding stage, is given for C. vicina as 5.12 days and for L. sericata as 5.81 days [45]. This temperature regime, however, is marginally suboptimal for L. sericata $[46,47]$, which resulted in slightly diminished oviposition, hatching activity, and sample sizes for this species (Tables 1 and 2).

Adams and Hall [6] noted that the rate of expansion in larvae was highest during the first $3 \mathrm{~h}$ in $80 \%$ ethanol. In our study, at least $25 \%$ of the fresh larvae were still alive after two 
hours. Placement of living larvae into liquids led to contraction in all samples, which is due to the long drowning and suffocation process. Some larvae were still alive after three hours. The early measurement data could therefore not be incorporated. This resulted in a lack of data on the initial length of larvae tested. There is, to our knowledge, only one method to measure living larvae using a geometrical micrometer [48]. This method, however, is not suited for measurement of 350 mobile larvae in a reasonable amount of time.

The first measurements were performed the next day to ensure the death of all larvae. Subsequent measurements after nine days and one month were conducted to account for potential revelations of new information in casework. It takes at least a few days for a previously unsuspicious domestic death to change into a potential crime due to newly discovered evidence. It can also take up to a few weeks until the samples are sent to a forensic entomologist. Handling of samples was restricted to avoid damages.

Even though the age of larvae was synchronized by limiting oviposition for $24 \mathrm{~h}$, the range in sizes was considerable (Table 1), with maximal sizes consistent with literature $[10,34,46]$. Biological variation in length within larvae of the same species was larger than the largest experimental difference in average lengths (Table 2). Size ranges are seldom specified in publications on development of forensically relevant insects. The provision of such data should be encouraged in publications on forensic entomology. It could contribute to the awareness of biological variation in entomological samples. Furthermore, analyses should not be based on larval sizes alone, but should incorporate the developmental stage in order to differentiate between an unusually large feeding larva and an unusually small postfeeding individual. Such tasks are especially difficult for nonexpert police personnel. It is therefore important to develop illustrated guidelines designed specifically for nonexperts in order to capacitate police personnel to perform useful insect collections.

The effects of alternative storage over all alcoholic beverages and both treatments were smaller in C. vicina than in L. sericata (Figure 2 and Table 2). This indicates that C. vicina might be a more robust fly species, which is also reflected in a wider temperature tolerance [47].

Comparison of HWK larvae showed that sizes of $C$. vicina larvae stored in the spirits vodka and brandy, as well as the liquor peppermint schnapps, were statistically similar to their controls in all measurements (Figure 2, Table 2). The effects of vodka and brandy were also statistically nonsignificant in HWK larvae of $L$. sericata after nine days and after one month. The European spirits regulation (EU Spirituosenverordnung [49]) defines vodka as a spirit gained from distillation of potatoes or grain. The maximal content of sugar allowed is $8 \mathrm{~g}$ per liter, alcohol content must be at least $37.5 \%$ vol. Brandy is a liquor produced by distilling wine and the sugar content allowed is no more than $35 \mathrm{~g}$ per liter, alcohol content must be at least $36 \%$ vol. Herbal liquors like Jägermeister and peppermint schnapps are required to contain at least $80 \mathrm{~g}$ sugar per liter and at least $15 \%$ vol. of alcohol.

This indicates that sugar content needs as much attention as alcohol content when trying to determine possible effects of storage media on samples of forensically important fly larvae.

The largest effect detected in this study did not arise from the choice of storing media, but treatment of larvae before storage. While HWK larvae of both species stored in vodka and brandy were similar to their HWK controls in $70 \%$ ethanol, all fresh larvae were significantly different. Size differences of freshly stored samples to controls diminished over time for both species, where the effect was more pronounced in C. vicina larvae (Figure 3). Longer storage times might partly balance initial shrinkage effects caused by missing fixation via HWK. Interestingly, of all storage media, $70 \%$ ethanol had the largest effect on fresh larvae of $C$. vicina over all measurements, while it had the least effect of fresh L. sericata larvae. This result must be investigated further.

The lengths of most larvae collected and stored in alternative liquids were smaller than those of their HWK controls in $70 \%$ ethanol. This indicates a need for cautious estimations of minimal PMIs when interpreting specimen stored in alternative liquids with lower alcohol concentrations. Calculations based on size might underestimate the real development time of inspected larvae stored in media similar to those investigated here. 


\section{Conclusions}

This study shows that storage of larvae in an alcoholic liquid is preferable to omitting collection at all due to lack of proper equipment. Subpar storage methods in weaker liquors than $70 \%$ ethanol did not have fatal effects on fly larvae or make them unusable for further examinations. The effect on fresh larvae was significant shrinkage compared to control samples. This can lead to an underestimation of developmental times. For larvae previously HWK on the other hand, spirits with high alcohol and low sugar contents were found to have almost negligible effects. HWK, and thus fixation of the larvae, should therefore always be aimed for when collecting fly larvae. It might help counteract effects of subpar storage media and increase comparability to existing data. It furthermore sterilizes the larvae and reduces degradation during longer storage times.

Exact documentation of treatments and storage liquids is imperative, especially in cases with makeshift methods. Casework in forensic entomology can never incorporate all influencing factors. Even less when working with external samples and/or a small amount of specimen and a lack of supplemental data. Such caveats must always be pointed out when asked specific questions in order to help an investigation. The denomination of insects developing on a human body as a "biological clock" increased expectations for the science of forensic entomology. In reality, the method cannot be as accurate as a clock, as determination of minimal PMI based on insect development must always be an estimation.

Funding: We acknowledge support by the German Research Foundation and the Open Access Publication Fund of the Thueringer Universitaets-und Landesbibliothek Jena Projekt-Nr. 433052568.

Institutional Review Board Statement: Not applicable.

Data Availability Statement: The data presented in this study are available on request from the corresponding author.

Acknowledgments: Thanks go to Roland Spieß for valuable editorial contributions and to Gita Mall for administrative support. Two anonymous reviewers provided constructive comments, which improved the manuscript.

Conflicts of Interest: The author declares no conflict of interest.

\section{References}

1. Byrd, J.H.; Tomberlin, J. Forensic Entomology: The Utility of Arthropods in Legal Investigations, 3rd ed.; CRC Press: Boca Raton, FL, USA; Taylor \& Francis Group: Boca Raton, FL, USA, 2019; p. 620.

2. Gennard, D.E. Forensic Entomology. An Introduction; Wiley Chichester: Hoboken, NJ, USA, 2007; p. 223.

3. Catts, E.P.; Goff, M.L. Forensic entomology in criminal investigations. Annu. Rev. Entomol. 1992, 37, 253-272. [CrossRef] [PubMed]

4. Greenberg, B.; Kunich, J.C. Entomology and the Law. Flies as Forensic Indicators; Cambridge University Press: Cambridge, UK, 2002; Volume 1, p. 306.

5. Amendt, J. Best practice in forensic entomology-Standards and guidelines. Int. J. Leg. Med. 2007, 121, 90-104. [CrossRef] [PubMed]

6. Adams, Z.J.O.; Hall, M.J.R. Methods used for the killing and preservation of blowfly larvae, and their effect on post-mortem larval length. Forensic Sci. Int. 2003, 138, 50-61. [CrossRef] [PubMed]

7. Bugelli, V.; Campobasso, C.P.; Verhoff, M.A.; Amendt, J. Effects of different storage and measuring methods on larval length values for the blow flies (Diptera: Calliphoridae) Lucilia sericata and Calliphora vicina. Sci. Justice 2017, 57, 159-164. [CrossRef] [PubMed]

8. Day, D.M.; Wallman, J.F. Effect of preservative solutions on preservation of Calliphora augur and Lucilia cuprina larvae (Diptera: Calliphoridae) with implications for post-mortem interval estimates. Forensic Sci. Int. 2008, 179, 1-10. [CrossRef] [PubMed]

9. Tantawi, T.I.; Greenberg, B. The Effect of Killing and Preservative Solutions on Estimates of Maggot Age in Forensic Cases. J. Forensic Sci. 1993, 38, 702-707. [CrossRef] [PubMed]

10. Richards, C.S.; Rowlinson, C.C.; Hall, M.J.R. Effects of storage temperature on the change in size of Calliphora vicina larvae during preservation in 80\% ethanol. Int. J. Leg. Med. 2013, 127, 231-241. [CrossRef] [PubMed]

11. Smith, K.E.; Wall, R. The use of carrion as breeding sites by the blowfly Lucilia sericata and other Calliphoridae. Med. Vet. Entomol. 1997, 11, 38-44. [CrossRef] [PubMed]

12. Hayes, E.J.; Wall, R.; E Smith, K. Measurement of age and population age structure in the blowfly, Lucilia sericata (Meigen) (Diptera: Calliphoridae). J. Insect Physiol. 1998, 44, 895-901. [CrossRef] 
13. Clark, K.; Evans, L.; Wall, R. Growth rates of the blowfly, Lucilia sericata, on different body tissues. Forensic Sci. Int. 2006, 156, 145-149. [CrossRef] [PubMed]

14. Davies, L. Lifetime reproductive output of Calliphora vicina and Lucilia sericata in outdoor caged and field populations; flight vs. egg production? Med. Vet. Entomol. 2006, 20, 453-458. [CrossRef] [PubMed]

15. Wooldridge, J.; Scrase, L.; Wall, R. Flight activity of the blowflies, Calliphora vomitoria and Lucilia sericata, in the dark. Forensic Sci. Int. 2007, 172, 94-97. [CrossRef] [PubMed]

16. Tarone, A.M.; Foran, D.R. Generalized Additive Models and Lucilia sericata Growth: Assessing Confidence Intervals and Error Rates in Forensic Entomology. J. Forensic Sci. 2008, 53, 942-948. [CrossRef] [PubMed]

17. Gallagher, M.B.; Sandhu, S.; Kimsey, R. Variation in Developmental Time for Geographically Distinct Populations of the Common Green Bottle Fly, Lucilia sericata (Meigen). J. Forensic Sci. 2010, 55, 438-442. [CrossRef] [PubMed]

18. Gunn, A.; Bird, J. The ability of the blowflies Calliphora vomitoria (Linnaeus), Calliphora vicina (Rob-Desvoidy) and Lucilia sericata (Meigen) (Diptera: Calliphoridae) and the muscid flies Muscina stabulans (Fallén) and Muscina prolapsa (Harris) (Diptera: Muscidae) to colonise buried remains. Forensic Sci. Int. 2011, 207, 198-204. [CrossRef]

19. Tarone, A.M.; Picard, C.J.; Spiegelman, C.; Foran, D.R. Population and Temperature Effects on Lucilia sericata (Diptera: Calliphoridae) Body Size and Minimum Development Time. J. Med. Entomol. 2011, 48, 1062-1068. [CrossRef] [PubMed]

20. Mai, M.; Amendt, J. Effect of different post-feeding intervals on the total time of development of the blowfly Lucilia sericata (Diptera: Calliphoridae). Forensic Sci. Int. 2012, 221, 65-69. [CrossRef] [PubMed]

21. Roe, A. Development Modeling of Lucilia sericata and Phormia regina (Diptera: Calliphoridae). Ph.D. Thesis, Nebraska-Lincoln, Lincoln, NE, USA, 2014.

22. Aubernon, C.; Charabidze, D.; Devigne, C.; Delannoy, Y.; Gosset, D. Experimental study of Lucilia sericata (Diptera Calliphoridae) larval development on rat cadavers: Effects of climate and chemical contamination. Forensic Sci. Int. 2015, 253, 125-130. [CrossRef]

23. Roe, A.; Higley, L.G. Development modeling of Lucilia sericata (Diptera: Calliphoridae). Peer J. 2015, 3, e803. [CrossRef] [PubMed]

24. Bernhardt, V.; Pogoda, W.; Verhoff, M.A.; Toennes, S.W.; Amendt, J. Estimating the age of the adult stages of the blow flies Lucilia sericata and Calliphora vicina (Diptera: Calliphoridae) by means of the cuticular hydrocarbon $n$-pentacosane. Sci. Justice 2017, 57, 361-365. [CrossRef]

25. Robinson, L.; Bryson, D.; Bulling, M.; Sparks, N.; Wellard, K. Post-feeding activity of Lucilia sericata (Diptera: Calliphoridae) on common domestic indoor surfaces and its effect on development. Forensic Sci. Int. 2018, 286, 177-184. [CrossRef]

26. Dimitrov, R.E.; Amendt, J.; Rothweiler, F.; Zehner, R. Age determination of the adult blow fly Lucilia sericata (Diptera: Calliphoridae) through quantitative pteridine fluorescence analysis. Forensic Sci. Med. Pathol. 2020, 16, 641-648. [CrossRef] [PubMed]

27. Kaib, M. Die Fleisch-und Blumenduftrezeptroen auf der Antenne der Schmeißfliege Calliphora vicina. J. Comp. Physiol. 1974, 95, 105-121. [CrossRef]

28. Reiter, C. Zum Wachstumsverhalten der Maden der blauen Schmeißfliege Calliphora vicina. Int. J. Leg. Med. 1984, 91, 295-308. [CrossRef]

29. Nunes, M.V.; Kenny, N.; Saunders, D. The photoperiodic clock in the blowfly Calliphora vicina. J. Insect Physiol. 1990, 36, 61-67. [CrossRef]

30. Sadler, D.; Fuke, C.; Court, F.; Pounder, D. Drug accumulation and elimination in Calliphora vicina larvae. Forensic Sci. Int. 1995, 71, 191-197. [CrossRef]

31. Saunders, D.S.; Bee, A. Effects of larval crowding on size and fecundity of the blow fly, Calliphora vicina (Diptera: Calliphoridae). Eur. J. Entomol. 1995, 92, 615-622.

32. Faucherre, J.; Cherix, D.; Wyss, C. Behavior of Calliphora vicina (Diptera, Calliphoridae) Under Extreme Conditions. J. Insect Behav. 1999, 12, 687-690. [CrossRef]

33. Kaneshrajah, G.; Turner, B. Calliphora vicina larvae grow at different rates on different body tissues. Int. J. Leg. Med. 2004, 118, 242-244. [CrossRef] [PubMed]

34. Donovan, S.E.; Hall, M.J.R.; Turner, B.D.; Moncrieff, C.B. Larval growth rates of the blowfly, Calliphora vicina, over a range of temperatures. Med. Vet. Entomol. 2006, 20, 106-114. [CrossRef]

35. Spieß, R.; Schoofs, A.; Heinzel, H.-G. Anatomy of the stomatogastric nervous system associated with the foregut in Drosophila melanogaster and Calliphora vicina third instar larvae. J. Morphol. 2008, 269, 272-282. [CrossRef]

36. Szpila, K.; Pape, T.; Rusinek, A. Morphology of the first instar of Calliphora vicina, Phormia regina and Lucilia illustris (Diptera, Calliphoridae). Med. Vet. Entomol. 2008, 22, 16-25. [CrossRef] [PubMed]

37. Martín-Vega, D.; Hall, M.J.R. Estimating the age of Calliphora vicina eggs (Diptera: Calliphoridae): Determination of embryonic morphological landmarks and preservation of egg samples. Int. J. Leg. Med. 2016, 130, 845-854. [CrossRef] [PubMed]

38. Zajac, B.K.; Amendt, J.; Verhoff, M.A.; Zehner, R. Dating Pupae of the Blow Fly Calliphora vicina Robineau-Desvoidy 1830 (Diptera: Calliphoridae) for Post Mortem Interval-Estimation: Validation of Molecular Age Markers. Genes 2018, 9, 153. [CrossRef] [PubMed]

39. Niederegger, S.; Gorb, S.; Jiao, Y. Contact behaviour of tenent setae in attachment pads of the blowfly Calliphora vicina (Diptera, Calliphoridae). J. Comp. Physiol. A 2002, 187, 961-970. [CrossRef] [PubMed]

40. Niederegger, S.; Spieß, R. Cuticular muscle attachment sites as a tool for species determination in blowfly larvae. Parasitol. Res. 2012, 110, 1903-1909. [CrossRef] [PubMed] 
41. Niederegger, S.; Wartenberg, N.; Spiess, R.; Mall, G. Influence of food substrates on the development of the blowflies Calliphora vicina and Calliphora vomitoria (Diptera, Calliphoridae). Parasitol. Res. 2013, 112, 2847-2853. [CrossRef]

42. Marchenko, M.I. Medicolegal relevance of cadaver entomofauna for the determination of the time of death. Forensic Sci. Int. 2001, 120, 89-109. [CrossRef]

43. Smith, K.G.V. A Manual of Forensic Entomology; The Trustees of the British Museum (Natural History): London, UK, 1986 ; Volume 1.

44. Smith, K.E.; Wall, R. Asymmetric competition between larvae of the blowflies Calliphora vicina and Lucilia sericata in carrion. Ecol. Entomol. 1997, 22, 468-474. [CrossRef]

45. Davies, L.; Ratcliffe, G.G. Development rates of some pre-adult stages in blowflies with reference to low temperatures. Med. Vet. Entomol. 1994, 8, 245-254. [CrossRef]

46. Grassberger, M.; Reiter, C. Effect of temperature on Lucilia sericata (Diptera: Calliphoridae) development with special reference to the isomegalen- and isomorphen-diagram. Forensic Sci. Int. 2001, 120, 32-36. [CrossRef]

47. Niederegger, S.; Pastuschek, J.; Mall, G. Preliminary studies of the influence of fluctuating temperatures on the development of various forensically relevant flies. Forensic Sci. Int. 2010, 199, 72-78. [CrossRef] [PubMed]

48. Villet, M.H. An inexpensive geometrical micrometer for measuring small, live insects quickly without harming them. Entomol. Exp. Appl. 2007, 122, 279-280. [CrossRef]

49. EUR-Lex, Access to Europen Union Law, Regulation (EU) 2019/787 on the Definition, Description, Presentation and Labelling of Spirit Drinks (EU-Spirituosenverordnung). Available online: https:/ / eur-lex.europa.eu/legal-content/DE/TXT/PDF/?uri= CELEX:32019R0787\&from=EN (accessed on 18 March 2021). 